\title{
ONTOLOGICAL MISCONCEPTION IN MATHEMATICS TEACHING IN ELEMENTARY SCHOOLS
}

\author{
Imam Kusmaryono*1, Mochamad Abdul Basir², Bagus Ardi Saputro ${ }^{3}$ \\ ${ }^{1,2}$ Universitas Islam Sultan Agung \\ ${ }^{3}$ Universitas PGRI Semarang
}

\section{Article Info}

Article history:

Received Oct 28, 2019

Revised Jan 29, 2020

Accepted Jan 30, 2020

\section{Keywords:}

Elementary Schools,

Misconception,

Ontology,

Teaching Mathematics

\begin{abstract}
Elementary school teachers in Indonesia are required to master many subjects to be taught to their students. It is undeniable that the teachers' mastery of knowledge (material) in some subjects inadequate. Therefore, it is worth to argue that there was a misconception in mathematics teaching in elementary schools. This research was designed using a qualitative approach. The participants of this study were 30 elementary school teachers in Semarang city area, Central Java province, Indonesia. The research data were obtained through questionnaires, and interviews. The purpose of the study was to discuss the types and causes of the misconception of mathematics teaching in elementary schools. Alternative solutions were also presented to problem-solving so that misconceptions do not occur anymore in mathematics teaching. The findings show that, teachers evenly experience types of misconceptions: (1) pre-conception, (2) under-generalization, (3) over-generalization, (4) modelling error, (5) prototyping error; and (6) process-object error in teaching mathematics in elementary schools. Some misconceptions have taken root and are difficult to remove, called "ontological misconceptions" because of teachers' years of belief that the knowledge they received was true when in fact it was not quite right.
\end{abstract}

Copyright $@ 2020$ IKIP Siliwangi. All rights reserved.

\section{Corresponding Author:}

Imam Kusmaryono,

Department of Mathematics Education,

Universitas Islam Sultan Agung

Jl. Kaligawe Raya No.KM. 4, Terboyo Kulon, Semarang, Central Java 50112, Indonesia

Email: kusmaryono@unissula.ac.id

\section{How to Cite:}

Kusmaryono, I., Basir, M. A., \& Saputro, B. A. (2020). Ontological misconception in mathematics teaching in elementary schools. Infinity, 9(1), 15-30.

\section{INTRODUCTION}

Teaching Math is a difficult task under any circumstances. This is because of the complexity, characteristics and nature of Mathematics itself. When beginning to study Mathematics, students learn it themselves and or learn from others, especially with their teachers (Skott, 2019). Often, in mathematics learning misconceptions occur that hinder students' cognitive development. Therefore the teacher must provide a careful explanation followed by opportunities that create opportunities for students to understand and absorb ideas that are presented clearly, so students become proficient in Mathematics (Sullivan, Clarke, Clarke, Farrell, \& Gerrard, 2013). 
The results of the survey in the last ten years conducted by the Program for International Student Assessment (PISA) and the survey by Trends in the International Mathematics and Science Study (TIMSS) stated that student achievement in learning mathematics in Indonesia is still at a lower level compared to several countries surveyed in the world (OECD, 2019). Talking about the low performance of Indonesian students in the field of mathematics, can not be separated from the existence of misconceptions in teaching.

Many research have focused on analyzing students' misconceptions in learning mathematics (Aliustaoğlu, Tuna, \& Biber, 2018; Gooding \& Metz, 2011; Mohyuddin \& Khalil, 2016; Sarwadi \& Shahrill, 2014). However, the authors have not discussed yet about teacher mistakes in Mathematics learning in school. Then a questionarised: Did the teacher involve as a causal factor of misconception in mathematics learning? Findings in this research are very important to analyze the misconception in mathematics teaching by teachers in elementary schools in Indonesia and analytical alternatives for problem solving to get rid of misconception

A teacher has a key role and position in the entire education process. The teacher is the main factor of students' learning success. Moreover, in elementary schools, teachers are required to master teaching materials and to develop teaching methods in accordance with the subjects taught (Anwar, 2012). Elementary School Teachers have the most heavy responsibilities in their professional duties compared to grade teachers middle school and high school level. An elementary school teacher in Indonesia is required to master many subjects, including Language, Mathematics, Geography, History, Cultural Arts and Skills. Therefore, it is undeniable that their mastery of knowledge (material) in some subjects is not edequate. On one hand, teachers master subjects and are proficient in the field of language learning, but on the other hand, mastery of the material by the teacher is inadequate and are not proficient in mathematics learning. If the teachers do not have mathematical skills in teaching, it will hinder the achievement of learning goals, and affect students' positive dispositions towards mathematics learning (Kusmaryono, Suyitno, Dwijanto, \& Dwidayati, 2019).

The results of observations of mathematics learning of elementary school teachers in the Central Semarang area, there are still many learning misconceptions. They lack mastery and are not proficient in mathematics. Therefore this research is very important to do, considering elementary school teachers are the first people to instill knowledge of mathematical concepts in formal education.

Mathematical proficiency is a skillfull quality that shows skills, competencies, knowledge, beliefs, and fluency in working on and teaching mathematics and being problem solvers who are proficient with high productive dispositions (Groves, 2012; Kilpatrick, Swafford, \& Findell, 2001). It is important for teachers to understand, that mathematical proficiency in teaching will have implications in learning that misconceptions will not occur, so that the teacher can become a facilitator who encourages students to become constructors of "constructive knowledge" for themselves students (Kistner, Rakoczy, Otto, \& Klieme, 2015).

The misconception of mathematics by teachers in a teaching process in elementary schools can result in misconceptions or misunderstanding of a sustainable basis which lead to higher education level. This is because the characteristics of mathematics learning materials are interrelated and continuous with other materials. To learn one of the mathematics topics at the advanced level must be based on reasoning from basic knowledge or prior prerequisite knowledge. If someone experiences a conceptual error (misconception) of mathematics in lower classes learning and is not immediately 
addressed, it will have an impact on the learning of mathematics in high classes (Flevares \& Schiff, 2014).

Misconceptions include understanding or thinking which is not based on true information. Misconceptions occur because of errors in transferring concepts from information obtained into a framework. So, the concept understood may not be in accordance with the actual concept. Teacher naturally forms ideas from everyday experience, but not all ideas developed are true in connection with evidence in a given discipline. In addition, some mathematical concepts in different content areas are very difficult to understand. Even teachers sometimes can have misconceptions about materials (Burgoon, Heddle, \& Duran, 2017). For them, it may be a very abstract concept, counter intuitive or quite complex. Therefore, changing a teacher's framework is the key to improving mathematics teaching for the better (Skott, 2019).

This paper outlines some of the misconceptions of teaching mathematics in elementary schools. In addition, it also provides alternative solutions to the problem, so that conceptual errors (misconceptions) do not occur anymore in mathematics teaching. Basically, every teacher has the potential to successfully carry out his/her duties as a reliable learning agent. Teacher's success can be clearly seen from the teaching skills and students' success in following the process and achieving learning goals (OECD, 2019).

\section{METHOD}

\subsection{Research Design}

This research used a qualitative approach. In this research, the hypothesis was not determined to be tested because the researcher wanted to get research findings that flowed and described the results of systematic observations (Creswell, 2014; McMillan \& Schumacher, 2014). This research was conducted during the active period of learning activities in elementary schools, precisely in January - February 2019.

\subsection{Participants}

The participants of this research were 30 elementary school teachers of first to sixth grades, representing 10 elementary schools in Central Semarang sub-district, Semarang city, Central Java province, Indonesia. The teachers have had teaching experiences in primary schools for 4 to 20 years.

\subsection{Procedure}

At the beginning of the research, observations of the mathematics teaching process were conducted in several elementary schools. Then, teachers completed questionnaires in the form of mathematical questions with answers written in the questionnaires. Responses of answers from questionnaires were identified and analyzed in terms of types of errors, then grouped into types of misconceptions: (1) pre-conception, (2) under-generalization, (3) over-generalization, (4) modelling error, (5) prototyping error; or (6) error processes (Ben-Hur, 2006; Diyanahesa, Kusairi, \& Latifah, 2017; Saputri \& Widyaningrum, 2016). Based on the misconception data, teacher representatives were then selected through a purposive snowball technique to get the subjects interviewed (Naderifar, Goli, \& Ghaljaie, 2017). The following is the flow of research implementation in Figure 1. 


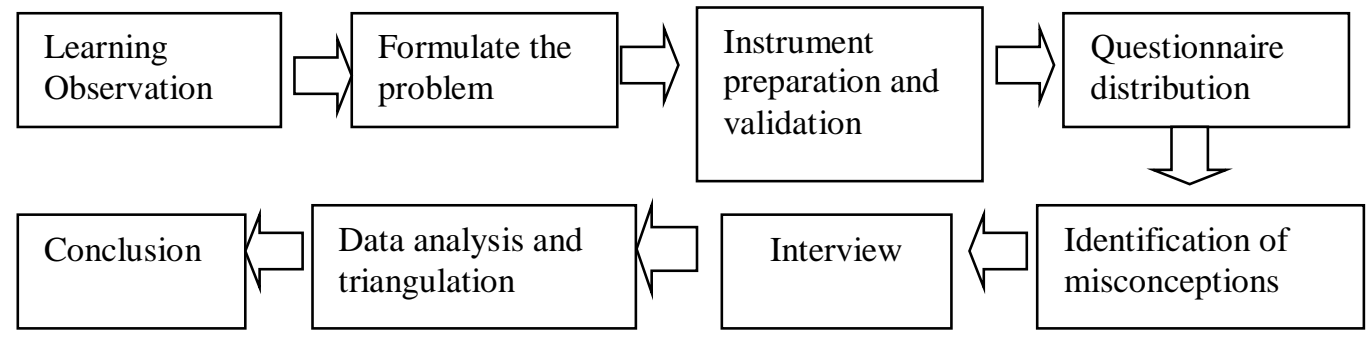

Figure 1. Research Flowcart

\subsection{Instruments}

Instruments for retrieving research data include questionnaires and a list of interview questions. The following is the flow of research implementation in Figure 1. The instrument was validated by experts in the field of mathematics learning, namely Dyana Wijayanti, Ph.D.The questionnaires contained six questions related to mathematics teaching materials and the teachers' perspectives on mathematics teaching. The questionnaire instruments in the form of questions were designed to explore responses of teachers' answers, types of errors and misconceptions in mathematics teaching in elementary schools. The list of interview questions was to reveal the causes of errors and misconceptions in mathematics teaching. The topics of mathematics teaching becoming the focus of this study were integers, flat geometry, rational numbers, and algebraic equations. Following are some examples of questionnaires used in this research instrument (Table 1).

Table 1. Example of Research Questionnaire

\begin{tabular}{|c|c|c|c|c|}
\hline No. & Question & Capable & $\begin{array}{c}\text { Not } \\
\text { Capable }\end{array}$ & $\begin{array}{l}\text { Give Answers and } \\
\text { Reasons }\end{array}$ \\
\hline 1 & $\begin{array}{l}\text { Are you able to read the mathematical } \\
\text { statement below? } \\
\text { (a) } 7+(-4)=3 \\
\text { (b) }-10-(-6)=-4\end{array}$ & & & \\
\hline 2 & $\begin{array}{l}\text { Are you able to prove that } 1.252525 \ldots \text { is } \\
\text { a rational number? }\end{array}$ & & & \\
\hline 3 & $\begin{array}{l}\text { Are you able to solve problems } \\
\frac{4}{9}: \frac{1}{3}=\ldots \\
\text { with procedures that you know about? }\end{array}$ & & & \\
\hline
\end{tabular}

\subsection{Data Collection, Analysis, and Triangulation}

The research data were collected through questionnaires and interviews. Subject as informants were the first to sixth-grade teachers teaching mathematics in elementary schools. This qualitative research data analysis was described as an interactively connected cycle through the stages of data collection, data reduction, data presentation, and conclusion (Miles \& Huberman, 2012; Moleong, 2007). To ensure the validity of the data, the researcher used the triangulation theory and source triangulation (Moleong, 2007). 


\section{RESULTS AND DISCUSSION}

\subsection{Results}

In the early stage of the study, observations of mathematics teaching processes were carried out in several elementary schools. The observations were conducted when teachers gave explanations of how to overcome problems experienced by students. The results of the observations showed that the teacher's explanation was more on conceptual or procedural categories and/or both. Successfully noted that the explanation from the teacher was sometimes illogical and not in accordance with the rules or mathematical principles. Whereas, based on the results of the responses to the questionnaire responses, several misconceptions related to mathematics teaching in elementary schools were found. The following are the misconception of mathematics teaching found (Table 2).

Table 2. Types of misconceptions in mathematics teaching

\begin{tabular}{lcccccc}
\hline Topic & \multicolumn{5}{c}{ Misconceptions Types } \\
\cline { 2 - 7 } & Type 1 & Type 2 & Type 3 & Type 4 & Type 5 & Type 6 \\
\hline Integers & $\checkmark$ & -- & -- & -- & -- & -- \\
\hline Rational number & -- & $\checkmark$ & $\checkmark$ & $\checkmark$ & $\checkmark$ & -- \\
\hline Linear equation & -- & -- & -- & -- & $\checkmark$ & -- \\
\hline Geometry field & $\checkmark$ & -- & -- & -- & -- \\
\hline $\begin{array}{l}\text { Note: Type 1=Pre-conception } \\
\text { Type 2=Under-generalization } \\
\text { Type 3=Over-generalization }\end{array}$ & & & $\begin{array}{l}\text { Type 4= Modelling error } \\
\text { Type 5= Process-object error } \\
\text { Type 6=Prototyping error }\end{array}$ \\
\hline
\end{tabular}

\section{Answer to Problem 1}

Problem 1 is the problem related to the teachers' understanding of symbol $(+)$ and $(-)$ as a sign of a count operation or integer name. Most respondents (teachers) had the same answers when it came to reading math sentences. Pay attention to the duplication of the respondents' answers in Figure 2a.

\section{Misconceptions}

(a) $7+(-4)=3$

Read: seven plus minus four equals to three

(b) $-10-(-6)=-4$

Read: minus ten substracted by minus six equals to minus four

\section{The alternative solution}

(a) $7+(-4)=3$

Read: seven plus negative four equals to three

(b) $\quad-10-(-6)=-4$

Read: negative ten minus negative six equals to negative four

Figure 2b. Alternative solution

Figure 2a. Respondent's Answer (R.02)

To clarify the information from the respondent (R.02), let us consider the following excerpt from the interview. 


$\begin{array}{lll}\text { Researcher } & : \begin{array}{l}\text { Do you understand the difference between of symbol (-) as } \\ \text { a sign of a count operation and (-) as an integer name? }\end{array} \\ \text { Respondent (R.02) } & : \begin{array}{l}\text { Symbol (-) is read minus. So symbol (-) can be a count } \\ \text { operation or number name. }\end{array} \\ \text { Researcher } & : \begin{array}{l}\text { In an integer system, there is a positive number (4) and a } \\ \text { negative number (-4), but there is no minus number. }\end{array} \\ \text { Respondent (R.02) } \quad: \quad \begin{array}{l}\text { Oh yeah, it's different. Now I understand symbol (-) as a } \\ \text { sign of a count operation and (-) as a negative integer } \\ \text { name }\end{array}\end{array}$

\section{Answer to Problem 2}

The problem to prove that $1.252525 \ldots$ is a rational number is a very important thing to explain thoroughly. Pay attention to the answer of the respondent in Figure $3 \mathrm{a}$.

\begin{tabular}{|c|c|}
\hline Misconceptions & The alternative solution \\
\hline Numbers $\quad=125$ rational numbers & $\begin{array}{l}\text { It will be proven that } 1.252525 \ldots \text { is a rational } \\
\text { number. } \\
\text { For example: } y=1.252525 \ldots \text { and } \\
\qquad 100 \mathrm{y}=125.252525 \ldots\end{array}$ \\
\hline So, $1.252525 \ldots=\frac{125}{100}$ & $\begin{array}{l}\text { Then } 100 \mathrm{y}=125.252525 \ldots \\
\begin{array}{r}\mathrm{y}=1.252525 \ldots \\
99 \mathrm{y}=124 \\
\mathrm{y}=\frac{124}{99}\end{array} \\
\text { So } 1.252525 \ldots=\frac{124}{99} \text { a rational number. }\end{array}$ \\
\hline
\end{tabular}

Figure 3a. Respondent's Answer (R.27)

Figure 3b. Alternative solution

The findings of the questionnaire analysis showed that the answers from the respondent were false. The following is an excerpt from the interview with one of the respondents (R.27).

Researcher

Respondent (R.27)

Researcher

Respondent (R.27)

Researcher

Respondent (R.27)
: Do you understand this number 1.252525 ... ?

: Number 1.252525 ... is an infinite number of repeated decimal places

: $\quad$ Is the number $1.25=1.252525 \ldots$ ?

: Yes, $1.25 \neq 1.252525 \ldots$... but this is difficult to prove in rational numbers.

: $\quad$ Pay attention, please, to the solution presented in Figure $3 b$. Now, do you understand?

: Yes, I do. Thanks for the explanation. 


\section{Answer to Problem 3}

The teaching of rational number division operations is always a serious concern in the procedural context. There are irregularities in the problem-solving process of $\frac{4}{9}: \frac{1}{3}=\cdots$

All of the respondents' answers for solving this problem were correct and no need to question. But the problem was the respondent could not explain why the fraction division operation was changed to a multiplication operation and the divider is reversed (Figure 4a).

\begin{tabular}{ll|}
\multicolumn{1}{|c|}{ Misconception } \\
$\frac{4}{9}: \frac{1}{3}=\frac{4}{9} x \frac{3}{1}=\frac{4 x 3}{9 x 1}=\frac{12}{9}=1 \frac{3}{9}=1 \frac{1}{3}$ & (a) $\frac{4}{9}: \frac{1}{3}=\frac{4: 1}{9: 3}=\frac{4}{3}=1 \frac{1}{3}$ \\
$\begin{array}{l}\text { There is a change in the distribution } \\
\text { operation mark into a multiplication } \\
\text { operation }\end{array}$ & (b) $\frac{4}{9}: \frac{1}{3}=\frac{4}{9}: \frac{3}{9}=\frac{4: 3}{9: 9}=\frac{4: 3}{1}=\frac{4}{3}=1 \frac{1}{3}$ \\
\hline
\end{tabular}

Figure 4a. Respondent's answer

Figure 4b. Alternative solution

Based on the finding of the questionnaires, it was found that the teacher's answer to the problem was correct (Figure 4a). However, the mathematical modelling presented as the solution to the problem could not precisely be explained with reasons given. The following interview excerpt is to strengthen this statement.

\begin{tabular}{|c|c|c|}
\hline Researcher & : & $\begin{array}{l}\text { Why } \frac{4}{9}: \frac{2}{3} \text { when you completed the division operation, did it } \\
\text { turn into a multiplication operation and the dividing } \\
\text { number becomes like this } \frac{4}{9} \times \frac{3}{2} ?\end{array}$ \\
\hline Respondent (R.02) & : & $\begin{array}{l}\text { I can't describe it correctly. I did a problem solving, as I } \\
\text { understood. }\end{array}$ \\
\hline Researcher & $:$ & Are you sure there is no other way to solve this problem? \\
\hline Respondent (R.02) & : & $\begin{array}{l}\text { I pretty am, there is no other way. All teachers solve this } \\
\text { problem as I did. }\end{array}$ \\
\hline Researcher & $:$ & Since when did you understand how to solve this? \\
\hline Respondent (R.02) & : & $\begin{array}{l}\text { Since I studied in elementary school } 25 \text { years ago. I } \\
\text { followed the teacher's instructions and I have been doing it } \\
\text { until now. }\end{array}$ \\
\hline
\end{tabular}

\section{Answer to Problem 4}

Figure $5 \mathrm{a}$ is an example of an erroneous understanding of teaching turning ordinary fractions into decimal fractions.

Paying attention to the respondent's answer (R.11) that the decimal form of $1 / 4$ is 0.25 is correct (Figure 5a). It was identified that the teaching process to get a 0.25 result 
was deemed inappropriate. Then the respondent confirmed (R.11) through the following interview.

\begin{tabular}{|c|c|}
\hline Researcher & $\begin{array}{l}\text { Why do you always add zero (0) number to each number } \\
\text { which is not divisible by four? }\end{array}$ \\
\hline Respondent (R.11) & $\begin{array}{l}\text { Number } 1 \text {, if added to zero }(0) \text { will be ten so that } 10 \text { can be } \\
\text { divided by } 4\end{array}$ \\
\hline Researcher & $\begin{array}{l}\text { Supposedly, } 1+0=1 \text {, it is not correct if } 1+0=10 ? \\
\text { How do you explain this to students? }\end{array}$ \\
\hline Respondent (R.11) & $\begin{array}{l}\text { I learned from mathematics teaching at previous schools. If } \\
\text { a number cannot be divided, then borrow zero }(0) \text { and the } \\
\text { result of the division is zero points (decimal). }\end{array}$ \\
\hline Researcher & $\begin{array}{l}\text { Are you not aware, that there has been a conceptual error } \\
\text { in this learning? }\end{array}$ \\
\hline Respondent (R.11) & $\begin{array}{l}\text { Sorry, I can't explain correctly. I realized that there has } \\
\text { been a teaching error, because all this time, I have only } \\
\text { followed the books and habits applied and carried out by all } \\
\text { the teachers at schools. }\end{array}$ \\
\hline
\end{tabular}

Below is shown the results of the subject's work in solving problem number 4 .

\begin{tabular}{|c|c|}
\hline Misconception & The alternative solution \\
\hline Change ordinary fractions $\frac{1}{4}$ Change ordinary & The solution should be as follows: \\
\hline fractions. & $1=\frac{1}{x} \times \frac{100}{1}$ \\
\hline The solution is by stacking as follows: & $\frac{\pi}{4}=\frac{-x}{100}$ \\
\hline 2). written zero point & $\frac{1}{1}=\frac{100}{4} \times \frac{1}{100}$ \\
\hline 1). borrow zero number & $\begin{array}{lcl}4 & 4 & 100 \\
1 & =25 \times 1\end{array}$ \\
\hline 1). borrow zero number & $\overline{4}=25 \times \overline{100}$ \\
\hline 8 & $1=25$ \\
\hline 3). borrow zero number & $\overline{4}-\overline{100}$ \\
\hline$\frac{20}{0}-$ & $\frac{1}{4}=0.25$ \\
\hline So, the decimal fraction of $\frac{1}{4}$ is 0.25 & $\begin{array}{l}\text { So, the decimal fraction } \\
\text { of } \frac{1}{4} \text { is } 0.25\end{array}$ \\
\hline
\end{tabular}

Figure 5a. Respondent's answer (R.11)

Figure 5b. Alternative solution

\section{Answer to Problem 5}

A process-object error was identified in the case (problem 5) of this study, namely the occurrence of an error in the completion process of a single variable linear equation (Figure 6a). 


\section{Misconception}

Determine the value of $x$, so that $2 x+5=17$ is correct

$2 \mathrm{x}+5=17$

$$
\begin{aligned}
2 \mathrm{x} & =17-5 \rightarrow ? ? ? \\
2 \mathrm{x} & =12 \\
\mathrm{x} & =\frac{12}{2} \\
\mathrm{x} & =6
\end{aligned}
$$

So, the solution $2 \mathrm{x}+5=17$ is $\mathrm{x}=6$

\section{The alternative solution}

Determine the value of $x$, so that $2 \mathrm{x}+5=17$ is correct

$$
2 x+5=17
$$$$
2 \mathrm{x}+5+(-5)=17+(-5) \rightarrow \text { Step } 1
$$$$
2 \mathrm{x}=12
$$

$$
\begin{aligned}
2 \mathrm{x} \cdot \frac{1}{2} & =12 \cdot \frac{1}{2} \rightarrow \text { Step } 2 \\
\mathrm{x} & =\frac{12}{2} \\
\mathrm{x} & =6
\end{aligned}
$$

So, the solution $2 \mathrm{x}+5=17$ is $\mathrm{x}=6$

Figure 6a. Respondent's answer (R.08)

Figure 6b. Alternative solution

If we look at Figure 6a, the result of the response answer is correct. However, the completion process in the second step on the right side displays a reduction operation with number 5 . Then the answer is confirmed through the interview below.
Researcher
: Is the completion process that you did right?
Respondent (R.08)
I'm sure, it is. Value of $x=6$
Researcher
Why is that in the second step $2 x=17$ - 5, like this?
Respondent (R.08)
: Number Positive 5 on the left segment is moved to the right segment to be negative (-5).

\section{Answer to Problem 6}

The misconception problem arises when the teacher was confronted with a flat square image. The teacher was asked to show the name of the parallelogram.

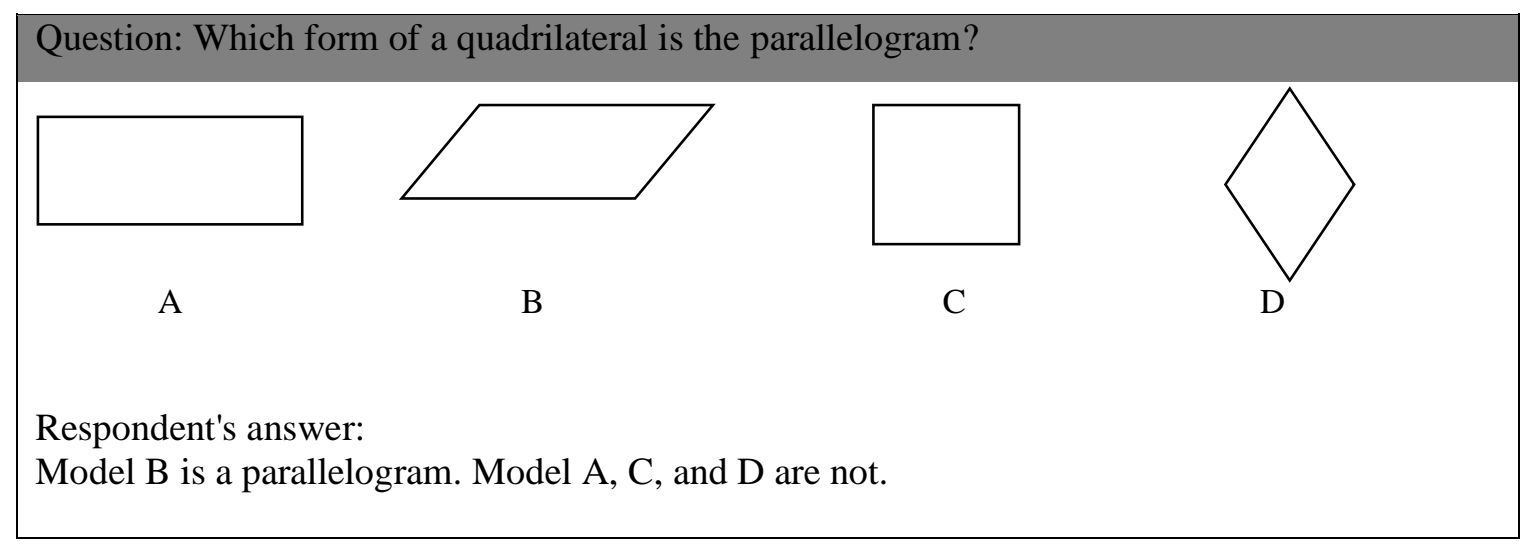

Figure 7. Quadrilateral models

The result of the respondent's answer stated that only one of the four images available was Figure B (Figure 7) considered a parallelogram. Then the respondent confirmed (R.02) through the following interview. 
Kusmaryono, Basir, \& Saputro, Ontological misconception in mathematics teaching ...

$\begin{array}{lll}\text { Researcher } & : & \text { Why did you choose image B as a parallelogram? } \\ \text { Respondent (R.02) } & : & \text { Because image B has a parallel hypotenuse } \\ \text { Researcher } & : & \text { Why are image A, C or D not? } \\ \text { Respondent (R.02) } & : & \text { A is a rectangle, C is a square, and D is a cube. } \\ \text { Researcher } & : & \text { Would you explain the definition of the parallelogram? } \\ \text { Respondent (R.02) } & : & \text { The parallelogram is a quadrilateral that has two pairs of } \\ & \text { sides facing the same length, there is an inclined side, and } \\ & \text { with equal angles. }\end{array}$

\subsection{Discussion}

\section{Problem 1: Pre-Conception}

It was identified that respondents experienced pre-conception, namely problems in reading integer symbols. They were not able to distinguish between symbol (+) or (-) as a count operation or integer name. Pre-conception is an initial mistake before someone understands the concept correctly (Diyanahesa et al., 2017). Based on the interview excerpts with the respondent (R.02), it can be said that the teacher failed to give an interpretation and interpreted the minus sign (-) as an operation to calculate the subtraction and negative in (-4) as the name of the number four negative. According to Cockburn and Littler's findings, integer material is one of the topics that is difficult to teach in embedding integer concepts (Cockburn \& Littler, 2008).

\section{Problem 2: Under-generalization}

Under-generalization is a more specific part of pre-conception. Undergeneralization is expressed as a limited understanding and ability to apply the concepts (Saputri \& Widyaningrum, 2016). This limited understanding explains various circumstances regarding teacher's knowledge during all mathematical ideas develop.

Cases in rational and irrational numbers may be one of the most problematic in mathematics teaching in elementary school. Many teachers only understand rational numbers as ordinary fractions, decimal fractions, and percent. In fact, fraction interpretation as a part-whole relationship is only a sub concept or one way of understanding rational numbers. The following under-generalization is identified from the response of the teacher's answer.

Teacher's mastery of the concept of rational numbers has not developed perfectly, the teacher only understands in a limited way. The alternative solution shown in Figure $2 b$ is the right step as a problem-solving instruction. Then the instructions on the number system must be able to answer the problem of under-generalization because there is an assumption that certain characteristics in the number system inhibit general understanding (Ben-Hur, 2006).

\section{Problem 3: Over-generalization}

Over-generalization is a case of misconception, where the application of concepts is not understood and the rules applied are considered irrelevant. Figure $3 \mathrm{a}$ is an example of an erroneous understanding of teaching in turning ordinary fractions into decimal fractions.

Based on the interview excerpt, it was indicated that the respondent (R.11) had misrepresented an illogical interpretation which caused a false understanding. Techniques for solving a mathematical problem can vary in ways, but the interpretation must generally 
be explained or understood by students (others). The solution in Figure $3 \mathrm{~b}$ shows that the strategy $\frac{1}{4} \times \frac{100}{100}$ was chosen because $\frac{100}{100}$ equals to 1 . In accordance with the algebraic law that all numbers, if multiplied by 1 are fixed, so that they are obtained $\frac{1}{4}=\frac{25}{100}=0.25$.

Through interviews with respondents (R.11), information was obtained that there had been an error (misconception) on mathematics teaching. During this time, the teaching of mathematics conducted by teachers only following books and habits that had been valid for many years. So it can be interpreted that there has been a rooted misconception that the concept of teaching believed to be true turns out that the concept of teaching is false (ontological misconception) (Ben-Hur, 2006). Ontological misconceptions in teaching mathematics occur because of the lack of mathematical knowledge from elementary school teachers.

\section{Problem 4: Modelling Error}

Modelling errors were identified when students (teachers) only imitated examples of wrong work from representations of rational number counting operations. In teaching rational number division operations, the teacher failed to give reasons through mathematical modelling displayed. An example of problems $\frac{4}{9}: \frac{2}{3}=\cdots$.

Mathematical modelling presented as a solution to the problem could not be explained precisely with given reasons. Apparently, the way of the respondent's (R.02) completion was obtained from their teacher while studying at the elementary level. They answered that the work process was obtained because of the teacher's beliefs and doctrines that had to be followed. A doctrine that they had just to accept without reasons because they assumed that mathematics is an exact science and the teacher never went wrong. The method of completion was replicated by students without knowing the reasons for the steps (Figure 4a). Such misconceptions are grouped as modelling errors. Compare it to the alternative solution in Figure $4 \mathrm{~b}$, it appears that the proposed alternative solution is very logical and consistent in accordance with mathematical principles.

Some teachers' answers in the questionnaire illustrate how limited understanding undermines the conception of key mathematical ideas. There is an opinion stating that maybe when the teachers experience a modelling error, the teachers have their own version of the model in the situation (Blazar \& Kraft, 2017). So, it can be interpreted that in this case, there is also a deep-rooted misconception, that is, the teaching concept which was believed to be true turns out that the teaching concept is false (ontological misconception) (Ben-Hur, 2006).

\section{Problem 5: Process-Object Error}

Process-object errors are identified in the case (problem 5), namely the occurrence of a process error completion from a single variable linear equation. If we look at Figure $5 \mathrm{a}$, the final result of the respondent's answer was correct. However, the completion process in the second step on the right side appeared a reduction operation with number 5. Confirmation was carried out through interviews, some teachers were very confident and believed that the process of solving a single variable linear equation was completed as in Figure 5a. They believed that the positive number on the left side, if moved to the right side, would change to a negative number. So it can be concluded that they do not understand the laws of algebra. The alternative solution in Figure $5 \mathrm{~b}$ is the best process for solving a single variable linear equation. The first step, the two segments get the same 
treatment, which is added to the same number $(-5)$, so that it still has the same value. The second step, multiplying the two segments with the same number $(1 / 2)$.

\section{Problem 6: prototyping error}

In the case (problem 6), the respondents refused to recognize that rectangles, squares, and rhombus are parallelograms. They did not understand the definition of parallelograms so it can be classified in the type of pre-conception. There were few respondents who could explain the definition of a parallelogram, that parallelogram is a quadrilateral which has two pairs of parallel equal sides and the opposite angles are equal. But in their minds, they still considered that image A, C, and D were not parallelograms. This misconception is classified in prototyping error. The teachers only understood the eternity of forms through a standard example of a parallelogram. The teacher considered the standard example of a concept to be the only type of example. The teacher did not understand the definition of a parallelogram, but only did representation through standard visual images.

Based on the explanation of the research findings discussed, it can be said that the things we have learned are sometimes not helpful in learning new concepts or theories. This happens when a new concept or theory is inconsistent with the material previously studied. Thus, it is very common for students, teachers, and adults to have misconceptions in different domains (content knowledge fields). Teachers evenly experience types of misconceptions: (1) pre-conception, (2) under-generalization, (3) over-generalization, (4) modelling error, (5) prototyping error; and (6) process-object error in teaching mathematics in elementary schools (Ben-Hur, 2006; Ryan \& Williams, 2007).

Misconceptions in teaching mathematics in elementary schools occur for several reasons. Teachers generally do not realize that the knowledge they have is incorrect. The teachers interpret new experiences through this erroneous understanding, thus disrupting the ability to understand new information correctly. Understanding incorrect mathematical concepts for years has been stable, permanent and rooted (Desstya, Prasetyo, Susila, Suyanta, \& Irwanto, 2019; Hughes, Lyddy, \& Lambe, 2013). The stable, permanent and rooted misconceptions are called "ontological misconceptions," in teachers' thinking. The ontological misconceptions relate to ontological beliefs, that is, beliefs about the category and nature of the world (Burgoon et al., 2011). Citing the opinion of Harisman et al that teaching experience (duration of teaching) is not a determinant of teacher professionalism, but the level of education and experience attending training is a factor that influences teacher proficiency in problem solving (O'Leary, Fitzpatrick, \& Hallett, 2017). So, it should be argued that the misconceptions that students have actually originated from their teacher "ontological misconception" in mathematics teaching in elementary schools.

Based on the research findings, to eliminate errors and misconceptions in mathematics teaching in elementary schools, it is recommended: (1) teachers always improve mathematical skills in terms of understanding learning theory, and mastering the core material of each subject of mathematics; (2) the mathematics ability to change the framework in mathematics teaching can be improved through workshops, seminars, discussions with mathematical experts and teacher working groups; (3) applying mathematical concepts in daily life, especially the use of reasons and thought to solve life problems in society so as to support changes in logical and critical thinking. 


\section{CONCLUSION}

The findings show that, teachers evenly experience types of misconceptions: (1) pre-conception, (2) under-generalization, (3) over-generalization, (4) modelling error, (5) prototyping error; and (6) process-object error in teaching mathematics in elementary schools. The findings of this research reveal that the math skills of elementary school teachers need to be improved. Various errors and misconceptions are oriented to conceptual and procedural errors in mathematics teaching. The misconceptions have been stable, permanent and rooted in "ontological misconception," in teacher thinking. The causes of misconceptions are (1) the teachers do not realize that the mathematical knowledge they have got because of teachers' years of belief that the knowledge they received was true when in fact it was not quite right.; (2) The mathematical knowledge possessed by the teachers have been accepted as rigid doctrines without any reasons to deny it for years. (3) the teachers' confidence in the knowledge they receive, is stable, permanent and rooted in "ontological misconception," in the teacher's thinking. (4) The teachers interpret new experiences through incorrect understanding, thus inhibiting the entry of new information correctly. Misconceptions tend to be very resistant to teaching and difficult to improve. Therefore, learning requires replacing or reorganizing the teacher's knowledge radically. Through math skills training, misconceptions can be replaced or eliminated by changing the framework of teaching mathematics.

\section{ACKNOWLEDGEMENTS}

The Authors would like to thank for the support to elementary school teachers in Semarang Tengah sub-district and LPPM Universitas Islam Sultan Agung who have helped smooth the research and funding assistance.

\section{REFERENCES}

Aliustaoğlu, F., Tuna, A., \& Biber, A. Ç. (2018). The misconceptions of sixth grade secondary school students on fractions. International Electronic Journal of Elementary Education, 10(5), 591-599. https://doi.org/10.26822/iejee.2018541308

Anwar, Z. (2012). Pelaksanaan pembelajaran matematika di sekolah dasar. Jurnal Penelitian Ilmu Pendidikan, 5(2).

Ben-Hur, M. (2006). Concept-rich mathematics instruction: Building a strong foundation for reasoning and problem solving. ASCD.

Blazar, D., \& Kraft, M. A. (2017). Teacher and teaching effects on students' attitudes and behaviors. Educational evaluation and policy analysis, 39(1), 146-170. https://doi.org/10.3102\%2F0162373716670260

Burgoon, J. N., Heddle, M. L., \& Duran, E. (2011). Re-examining the similarities between teacher and student conceptions about physical science. Journal of Science Teacher Education, 22(2), 101-114. https://doi.org/10.1007/s10972-010-9196-x

Cockburn, A. D., \& Littler, G. (2008). Mathematical Misconceptions: A Guide for Primary Teachers (Vol. III). California: SAGE Publications. https://doi.org/10.4135/9781446269121

Creswell, J. W. (2014). Research design: Qualitative, quantitative, and mixed methods approaches. Sage publications. 
Desstya, A., Prasetyo, Z. K., Suyanta, Susila, I., \& Irwanto (2019). Developing an Instrument to Detect Science Misconception of an Elementary School Teacher. International Journal of Instruction, 12(3), 201-218. https://doi.org/10.29333/iji.2019.12313a

Diyanahesa, N. E. H., Kusairi, S., \& Latifah, E. (2017). Development of misconception diagnostic test in momentum and impulse using isomorphic problem. Journal of Physics: Theories and Applications, 1(2), 145-156. https://doi.org/10.20961/jphystheor-appl.v1i2.19314

Flevares, L. M., \& Schiff, J. R. (2014). Learning mathematics in two dimensions: A review and look ahead at teaching and learning early childhood mathematics with children's literature. Frontiers in Psychology, 5, 459. https://doi.org/10.3389/fpsyg.2014.00459

Gooding, J., \& Metz, B. (2011). From misconceptions to conceptual change. The Science Teacher, 78(4), 34.

Groves, S. (2012). Developing mathematical proficiency. Journal of science and mathematics education in Southeast Asia, 35(2), 119-145.

Hughes, S., Lyddy, F., \& Lambe, S. (2013). Misconceptions about psychological science: A review. Psychology Learning \& Teaching, 12(1), 20-31. https://doi.org/10.2304/plat.2013.12.1.20

Kilpatrick, J. Swafford, J. \& Findell, B. (2001). Adding it up: Helping children learn mathematics. Mathematics Learning Study Committee: National Research Council.

Kistner, S., Rakoczy, K., Otto, B., Klieme, E., \& Büttner, G. (2015). Teaching learning strategies. The role of instructional context and teacher beliefs. Journal for educational research online, 7(1), 176-197.

Kusmaryono, I., Suyitno, H., Dwijanto, D., \& Dwidayati, N. (2019). The Effect of Mathematical Disposition on Mathematical Power Formation: Review of Dispositional Mental Functions. International Journal of Instruction, 12(1), 343356. https://doi.org/10.29333/iji.2019.12123a

McMillan, J. H., \& Schumacher, S. (2014). Research in education: Evidence-based inquiry. Harlow, UK.

Miles, M. B., \& Huberman, M. A. (2012). Analisis Data Kualitatif: Buku Sumber Tentang Metode-Metode Baru. Universitas Indonesia_UI Press (11th ed.). Jakarta: Universitas Indonesia (UI-Press).

Mohyuddin, R. G., \& Khalil, U. (2016). Misconceptions of Students in Learning Mathematics at Primary Level. Bulletin of Education and Research, 38(1), 133-162.

Moleong, L. J. (2007). Metodologi penelitian kualitatif edisi revisi. Bandung: PT Remaja Rosdakarya.

Naderifar, M., Goli, H., \& Ghaljaie, F. (2017). Snowball sampling: A purposeful method of sampling in qualitative research. Strides in Development of Medical Education, 14(3), 1-6. https://doi.org/10.5812/sdme.67670

O'Leary, K., Fitzpatrick, C. L., \& Hallett, D. (2017). Math anxiety is related to some, but not all, experiences with math. Frontiers in psychology, 8, 2067. https://doi.org/10.3389/fpsyg.2017.02067 
OECD. (2019). PISA 2018 : Insights and Interpretations. Retrieved from https://www.oecd.org/pisa/PISA\%202018\%20Insights\%20and\%20Interpretations\% 20FINAL\%20PDF.pdf

Ryan, J., \& Williams, J. (2007). Children's mathematics 4-15: learning from errors and misconceptions: learning from errors and misconceptions. McGraw-Hill Education (UK).

Saputri, D. A. F, \& Widyaningrum, T. (2016). Misconceptions Analysis on the Virus Chapter in Biology Textbooks for High School Students Grade X. International Journal of Active Learning, 1(1), 31-37.

Sarwadi, H. R. H., \& Shahrill, M. (2014). Understanding students' mathematical errors and misconceptions: The case of year 11 repeating students. Mathematics Education Trends and Research, 2014(2014), 1-10. https://doi.org/10.5899/2014/metr-00051

Skott, J. (2019). Understanding mathematics teaching and learning "in their full complexity." Journal of Mathematics Teacher Education, 22(5), 427-431. https://doi.org/10.1007/s10857-019-09446-Z

Sullivan, P., Clarke, D. J., Clarke, D. M., Farrell, L., \& Gerrard, J. (2013). Processes and priorities in planning mathematics teaching. Mathematics Education Research Journal, 25(4), 457-480. https://doi.org/10.1007/s13394-012-0066-Z 
